\title{
Betonarme Perdelerin Plandaki Yerleşimlerinin Kirişsiz Döşemeli Yapılara Etkisinin İncelenmesi
}

\begin{abstract}
Ali BOZER ${ }^{1}$
ÖZ

$\mathrm{Bu}$ çalışmada perdelerin plandaki yerleşiminin kirişsiz döşemeli yapıların deprem performansına olan etkileri araştırılmıştır. $\mathrm{Bu}$ amaç ile perdelerin plandaki yerleşimleri burulma düzensizliği yaratmayacak şekilde simetrik ve burulma düzensizliği yaratacak şekilde düzensiz seçilerek iki ayrı 7 katlı kirişsiz döşemeli yapı tasarlanmış ve bu yapıların deprem performansı doğrusal olmayan artımsal itme analizleri ve zaman tanım aralığında analizler ile irdelenmiştir. Elde edilen sonuçlara göre perdelerin plandaki yerleşimlerinin yapının sünekliği açısından belirleyici olduğu gözlemlenmiştir.
\end{abstract}

Anahtar Kelimeler: Kirişsiz döşeme, deprem performansı, betonarme perde, artımsal itme analizi, zaman tanım aralığında analizler, doğrusal olmayan davranış.

\begin{abstract}
Effect of Plan Configuration of Reinforced Concrete Shear Walls on the behavior of Flat Slab Buildings

In this study, the effect of plan configuration of shear walls on the behavior of flat slab building is investigated. For this purpose two seven-story flat slab buildings are designed. In one of the buildings, plan configuration of shear walls is selected symmetrical, whereas in the other building plan configuration is selected to cause torsional irregularity. Seismic performances of both buildings are then investigated by push-over and time-history analyses. It is observed that plan configuration of structural walls has a significant effect on overall ductility of the flat slab buildings.
\end{abstract}

Keywords: flat slab, seismic performance, shear wall, push-over analysis, time history analyses, non-linear behavior.

\footnotetext{
Not: Bu yazı

- Yayın Kurulu'na 14 Mart 2018 günü ulaşmıştır. 12 Kasım 2018 günü yayımlanmak üzere kabul edilmiştir.

- 31 Mart 2020 gününe kadar tartışmaya açıktır.

- https://doi.org/10.18400/tekderg.406060
}

1 Nuh Naci Yazgan Üniversitesi, İnşaat Mühendisliği Bölümü, Kayseri - bozerali@gmail.com https://orcid.org/0000-0002-3632-2605 


\section{GíRiş}

Alp-Himalaya deprem kuşağı üzerinde yer alan ülkemizde bazı büyük șehirlerimizin deprem tehlikesi yüksek olan bölgelerde kuruldukları, nüfusumuzun yarıdan fazlasının bu sahalarda yaşadığı göz önüne alındığında Türkiye deprem riski açısından dünyanın en önde gelen ülkelerindendir. Depremden dolayı oluşan hasarlar sadece depremin büyüklüğüne bağlı değil mühendislik yapılarının performansına da bağlıdır. Bu sebeple yapıların doğru taşıyıcı sistem seçilerek tasarlanması ve detaylandırılması oldukça önemlidir.

Deprem kuvvetlerinin yapıya olan etkileri seçilen taşıyıcı sisteme bağlı olarak değişiklik göstermektedir. Perdelerin plandaki yerleşimleri, seçilen döşeme sistemi ve yapısal düzensizlikler gibi birçok faktör yapının deprem davranışı üzerinde etkili olmaktadır [1]. Kirişsiz döşemeli sistemlerin yapı sünekliğini olumsuz etkilediği bilinmekle birlikte gerek bu sistemlerin imalat kolaylığı ve ekonomik üstünlükleri gerekse mekânları rahat ve etkin kullanma isteği, kirişsiz döşeme sistemlerinin giderek daha çok tercih edilmesine sebebiyet vermiştir.

Kirişsiz döşemeler betonarme plakların kirişlere mesnetlenmeden yüklerini doğrudan kolonlara aktardığı taşıyıcı sistemlerdir. Kirişsiz döşemelerin düşey yükler altındaki davranışı iyi anlaşılmıştır ve bu konu ile ilgili birçok çalışma mevcuttur. Öte yandan kirişsiz döşeme sisteminin özellikle deprem yüklerinin dinamik etkisi altındaki davranışı ile ilgili çalışmalar sınırlı kalmıştır. Mulcahy ve Rotter [2] kirişsiz döşeme ve kolon sisteminin moment-dönme ilişkilerini incelemiş, Chow ve Selna [3] deprem sırasında dengelenmemiş momentlerin döşemede yüksek kayma gerilmeleri oluşturduğunu tespit etmiş̧ir. Hwang ve Moehle [4] tersinir yükler altında döşeme davranışını ve eğilme momentlerinin dağılımını incelemiştir. Erberik ve Elnashai [5] kirişsiz döşemeli sistemler için kırılganlık analizleri gerçekleştirmiş ve kirişsiz döşemeli sistemlerin çerçeve sistemlere nazaran deprem hasarına daha eğilimli olduğunu tespit etmiştir. Coelho vd. [6] deprem yükleri altında kirişsiz döşeme davranışını değişken kesit ölçüleri ve farklı kolon yerleşimleri için incelemiştir. Almeida vd. [7] kirişsiz döşemelerin zımbalama davranışını tersinir yatay yükler ve düşey yüklerin birleşik etkisi altında irdelemiştir.

Her ne kadar kirişsiz döşeme sistemlerinin geleneksel kirişli döşeme sistemlerine nazaran mimari esneklik, daha az kısıtlanmış alan, daha kolay kalıp iş̧̧iliği ve daha hızlı inşa edilebilme gibi üstünlükleri olsa da yapılan çalışmalar göstermektedir ki kirişsiz döşemeli yapıların yanal rijitliği kirişli döşemeli yapılara kıyasla daha az olmaktadır. Bu durumda oluşan aşırı deformasyonlar hem yapısal olmayan elemanların hasar görmesine sebebiyet verebilmekte hem de ikinci mertebe etkilerinin daha fazla olmasına yol açmaktadır. Bununla birlikte kirişsiz döşemeli yapılarda döşeme içinde sargı donatısı kullanılmadığından döşeme kesitinin sünek davranış kabiliyeti ve enerji yutma kapasitesi oldukça sınırlı kalmakta, \%1 \%1.5 göreli öteleme seviyelerinde bile kirişsiz döşemeli sistemlerin yatay yük taşıma kapasitesini kaybettiği gözlemlenmektedir [7, 8, 9]. Bu sebeplerden ötürü Deprem Bölgelerinde Yapılacak Binalar Hakkındaki Yönetmelik'te (DBYBHY) [10] kirişsiz döşemeli sistemlerin süneklik düzeyi normal sistemler olarak dikkate alınması öngörülmüş, Türkiye Bina Deprem Yönetmeliğinde (TBDY) [11] ise kirişsiz döşemeli sistemlerde oluşabilecek hasarları sınırlamak için deprem etkilerinin tamamının betonarme perdeler tarafından karşılanması zorunlu kılınmıştır. 
Depreme dayanıklı yapı tasarımında perdelerin temel görevi tersinir deprem yükleri altında yapının yatay öteleme rijitliğini artırmak ve katlar arasında yatay ötelenmeleri sınırlandırmaktır [12]. Yapının deprem esnasında göstereceği davranış yapıdaki perde alanı ve plandaki perde yerleşimi ile ilgilidir. Bir yapıda perde oranları uygun seçilse bile perdelerin planda düzgün yerleştirilmemesi, taşıyıcı sistemin daha çok zorlanmasına sebep olabilmektedir [13].

TBDY [11]'e göre kirişsiz döşemeli betonarme sistemlerde deprem etkilerinin tamamının betonarme perdeler ile karşılanması gerekmektedir. Bu koşulu sağlamak için birinci aşamasında çerçeve kolonlarının alttan ve üstten mafsallı alındığı, ikinci aşamasında ise bu elemanların bağlantılarının monolitik modellendiği iki aşamalı bir hesaplama yöntemi önerilmektedir. $\mathrm{Bu}$ koşulu perdeleri planda düzgün yerleştirilmemiş ve burulma düzensizliğine sahip bir yapı için de sağlamak mümkündür. Bu tür bir tasarımda kolonlardan ve kirişsiz döşemelerden oluşan çerçeve sistemin şekildeğiştirme taleplerinin karşılanmasında perdelerin etkinliğinin daha az olacağı düşünülmektedir.

$\mathrm{Bu}$ çalışmada plandaki perde yerleşimlerinin kirişsiz döşemeli yapılara olan etkisi incelenmiştir. Perdelerin plandaki yerleşimleri burulma düzensizliği yaratmayacak şekilde simetrik ve burulma düzensizliği yaratacak şekilde düzensiz seçilerek iki ayrı yapı tasarlanmış ve bu yapıların deprem performansı doğrusal olmayan artımsal itme analizleri ve zaman tanım aralığında analizler ile irdelenmiştir.

\section{KIRIŞSIZ DÖŞEME SISTEMLERI'NIN TASARIMI}

Kirişsiz döşemeli sistemlerin analizi ve tasarımı için sonlu elemanlar yöntemi, moment katsayıları yöntemi, eşdeğer çerçeve yöntemi, akma çizgileri yöntemi ve benzeri yöntemler kullanılmaktadır. $\mathrm{Bu}$ yöntemler arasında eşdeğer çerçeve yöntemi, kirişsiz döşemeli sistemlerin analizi için İngiliz (BS8110) [14] ve Amerikan (ACI 318-11) [15] yönetmelikleri gibi uluslararası yönetmeliklerde olduğu gibi ulusal yönetmeliğimizde de (TSE-500) [16] yer bulmuş pratik bir yöntemdir. Düzgün yayılı düşey yükler altında kirişsiz döşeme sisteminde oluşan dönmelerin kolon yüzünden uzaklaştıkça arttığı bilinmektedir. Eşdeğer çerçeve yönteminde döşeme kirişinin faydalı genişliği dönmelerdeki değişimin sabit kabul edilebileceği bir kiriş genişliği belirlenerek hesaplanır. Burada kolonların düzgün bir aks sisteminde yerleştirildiği kabul edilmektedir. Faydalı kiriş genişliği betonarme elemanların rijitlikleri temel alınarak hesaplanmakta, dayanım faktörü ihmal edilmektedir. Yöntem orijinal olarak düşey yükler için geliştirilmiş, 1983 yılından itibaren yanal yükler altındaki davranışı da kapsayacak şekilde genişletilmiştir [17].

Eşdeğer çerçeve yönteminde kirişsiz döşemeler birbirlerine dik doğrultuda çerçeveler olarak idealleştirilirler. Bu yaklaşımda yatay eğilme elemanın genişliği çerçeveye dik iki komşu döşemenin açıklık ortaları arasındaki uzaklık olarak alınır ve her iki doğrultuda döşeme yükünün tamamı hesaba katılır. Çerçeve çözümlemesinden bulunan momentler yönetmelikte tanımlanan moment dağıtma katsayıları oranında kolon ve orta şeritlere dağıtılır. Mevcut binaların güçlendirilmesinde ve değerlendirilmesinde sıklıkla kullanılan bir standart olan ASCE41-13 [18]'de betonarme kirişsiz döşemelerin doğrusal olmayan davranışının modellenebilmesi için kirişsiz döşemeli sistemlerin eşdeğer çerçeveler olarak idealleştirilmesine izin verilmektedir. Eşdeğer çerçeve yönteminde eşdeğer döşeme kirişlerinin rijitliği bürüt kesit üzerinden hesaplanmaktadır. Öte yandan yapılan araştırmalar 
eşdeğer çerçeve yönteminde hesaplanan yatay rijitliklerin, doğrusal olmayan bölgede döşemede oluşacak çatlakların dikkate alınarak düşürülmesi gerektiğini göstermektedir $[19,20]$. Bu çalışmada kirişsiz döşemelerde tasarım yükleri altında donatı taleplerini belirlemek için sonlu elamanlar yöntemi ile modelleme yapılmış, döşemelerin doğrusal olmayan davranışını inceleyebilmek için eşdeğer çerçeve yöntemi kullanılmıştır. Doğrusal olmayan analizlerde göz önüne alınan kirişsiz döşeme sistemi için eşdeğer döşeme kirişi genişliği kenar eksenlerde $1.50 \mathrm{~m}$, iç eksenlerde $3.00 \mathrm{~m}$ kabul edilmiştir.

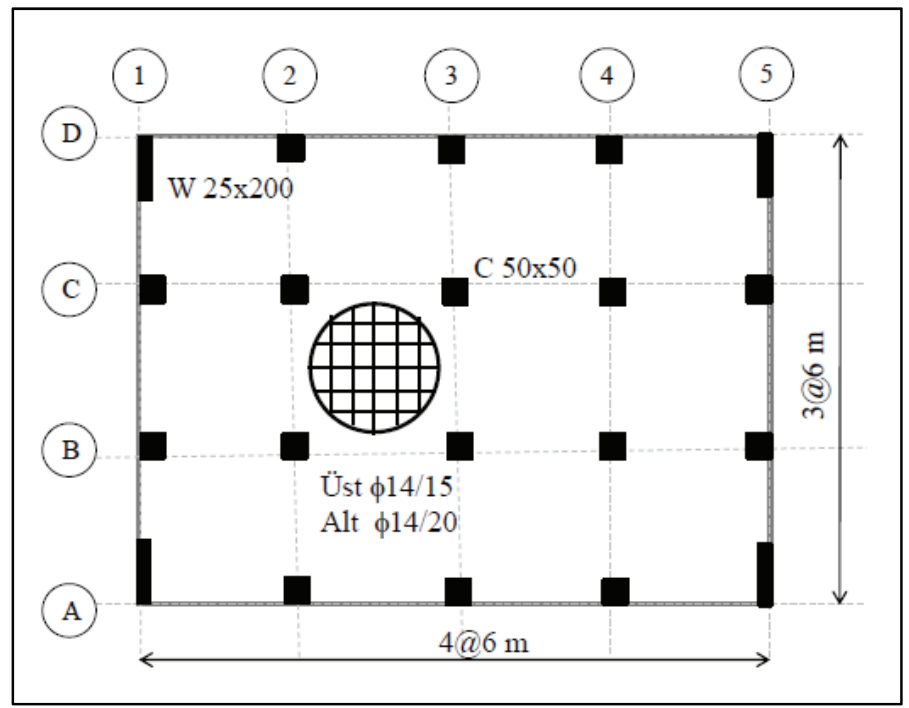

Şekil 1 - Düzenli yapı kat kalıp planı ve döşeme donatı şeması

Perdelerin plandaki yerleşiminin kirişsiz döşemeli yapıların deprem performansına olan etkilerinin araştırılması amacıyla kirişsiz döşemeli 7 katlı iki betonarme yapı tasarlanmıştır. Yapı kat yüksekliği $3.0 \mathrm{~m}$ alınmıştır. Yapılar ETABS v.16 [21] yapısal analiz programı kullanılarak tasarlanmış ve analiz edilmiştir. Yapılarda C30 beton sınıfı ve S420 donatı sınıfı kullanılmıştır. Döşeme kalınlığı yeterli zımbalama dayanımını sağlayacak şekilde $25 \mathrm{~cm}$ seçilmiş, döşemelere gelen kaplama yükü $2 \mathrm{kN} / \mathrm{m}^{2}$ ve hareketli yük $3.5 \mathrm{kN} / \mathrm{m}^{2}$ (ayırıcı duvar yükleri dahil) alınmıştır. Eğilme etkisi altındaki betonarme elemanlarda çatlamış kesite ait etkin rijitlik çarpanları kolonlar için 0.70 , döşemeler için 0.25 ve perdeler için düzlem içi 0.5 , düzlem dışı 0.25 alınmıştır. Deprem Yer Hareketi Düzeyi-2 (DD-2) ve Yerel Zemin Sınıfı ZC için Kısa Periyot Tasarım Spektral İvme Katsayısı ( $\left.\mathrm{S}_{\mathrm{DS}}\right) 1.0$ g, $1.0 \mathrm{~s}$ Periyot için Tasarım Spektral İvme Katsayısı $\left(\mathrm{S}_{\mathrm{D} 1}\right) 0.45 \mathrm{~g}$ kabul edilmiştir. Taşıyıcı sistem davranış katsayısı $\mathrm{R}$ her iki doğrultuda "Deprem etkilerinin tamamının süneklik düzeyi yüksek boşluksuz betonarme perdeler ile taşındığg” yapı için 6 alınmıştır. Betonarme perdeler her iki yapı için TBDY [11]'de belirtilen perde koşullarını sağlayacak şekilde seçilmiştir. Bu yapıların birinde (Şekil 1) perdeler planda burulma düzensizliği yaratmayacak şekilde simetrik yerleştirilmiş, diğer yapıda ise (Şekil 2) perdeler planda burulma düzensizliğine sebebiyet verecek şekilde düzenlenmiştir. Yapıya ait parametreler Tablo 1'de, eleman boyutları ve donatı detayları Şekil 3'te verilmiştir. 
Düzenli yapıda burulma düzensizliği katsayısı 1.04 olarak, düzensiz yapıda ise 1.73 olarak hesaplanmıştır. Beklenildiği gibi düzensiz yapıda hakim titreşim periyoduna karşılık gelen modal şekil değiştirmelerde öteleme ve burulma etkileri beraber görülmektedir. Bu nedenle düzensiz yapıda öteleme doğrultusunda modal kütle katılım oranı düzenli yapıya göre daha az olmaktadır. Düzensiz yapının burulma rijitliği düzenli yapıya göre daha azdır. Bu durum düzensiz yapıda öteleme ve burulma etkilerinin beraber görüldüğü y doğrultusu hakim titreşim periyodunun düzenli yapıda sadece öteleme etkilerinin bulunduğu hakim titreşim periyoduna kıyasla daha büyük çıkmasıyla da anlaşılabilmektedir. Hakim titreşim periyodundaki farklılığa bağlı olarak yapı toplam taban kesme kuvveti düzenli yapıda düzensiz yapıya oranla daha büyük hesaplanmıştır.

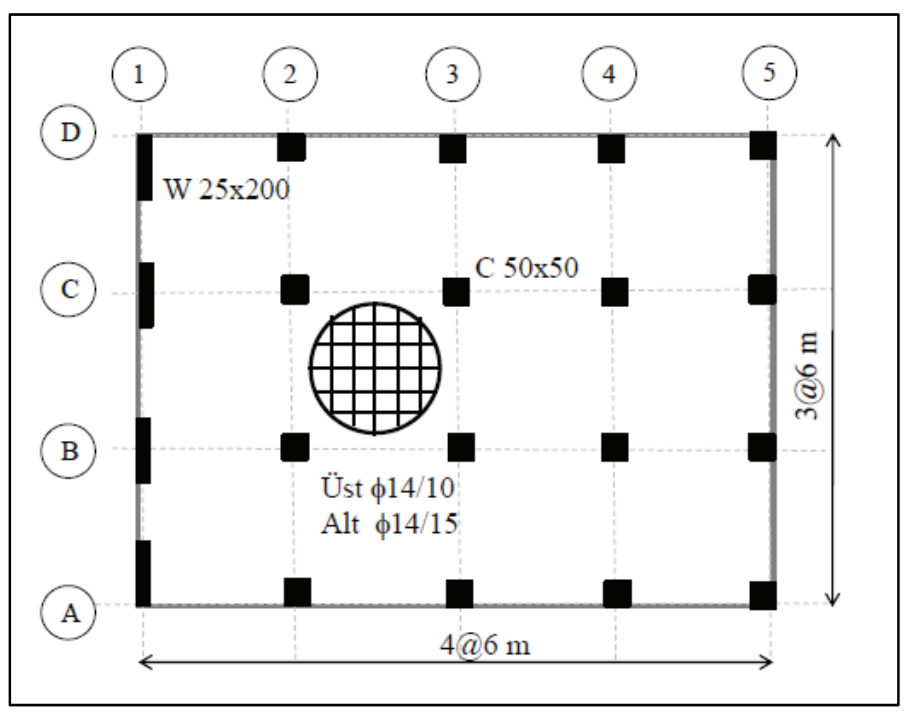

Şekil 2 - Düzensiz yapı kat kalıp planı ve döşeme donatı şeması

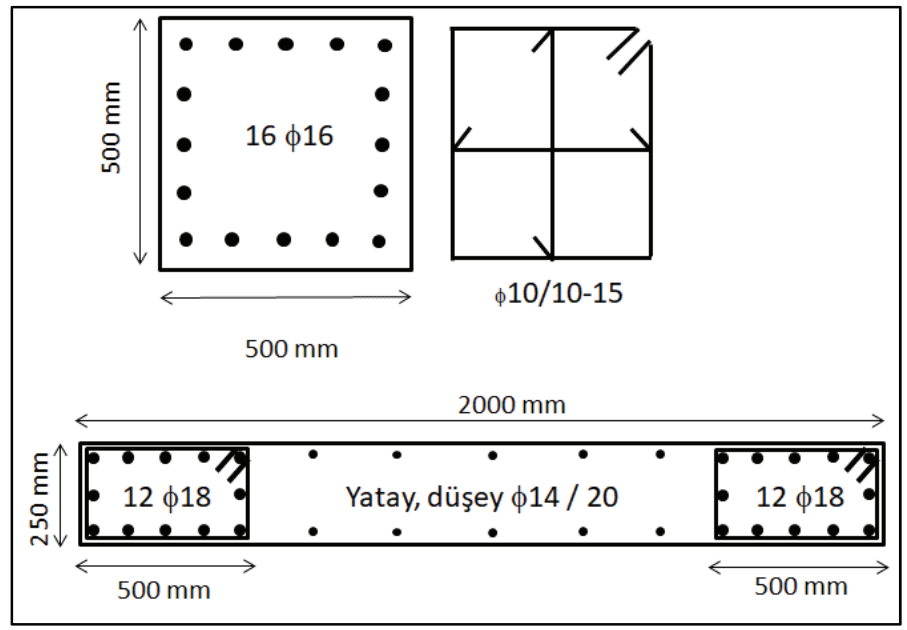

Şekil 3 - Kolon ve perde detayları 
Tablo 1 - Yapisal Parametreler

\begin{tabular}{|c|c|c|}
\hline \multirow{2}{*}{ Mod Birleştirme Yöntemi Büyütme Katsayısı } & Düzenli Yap1 & 1.01 \\
\hline & Düzensiz Yap1 & 1.23 \\
\hline \multirow{2}{*}{ Toplam Taban Kesme Kuvveti } & Düzenli Yap1 & $2026 \mathrm{kN}$ \\
\hline & Düzensiz Yap1 & $1690 \mathrm{kN}$ \\
\hline \multirow{2}{*}{$\begin{array}{l}\text { Y doğrultusu Hakim Titreşim periyodu /Y } \\
\text { doğrultusu Modal Etkin Kütle Oranı }\end{array}$} & Düzenli Yap1 & $1.41 \mathrm{~s} / \% 71$ \\
\hline & Düzensiz Yap1 & $1.95 \mathrm{~s} / \% 53$ \\
\hline \multirow{2}{*}{ Maks. Etkin Göreli Kat Ötelenmesi } & Düzenli Yapı & 0.011 (Kat 4) \\
\hline & Düzensiz Yap1 & 0.019 (Kat 3) \\
\hline \multirow{2}{*}{ Maks. Burulma Düzensizliği katsayısı $\eta_{\mathrm{bi}}$} & Düzenli Yap1 & 1.04 \\
\hline & Düzensiz Yap1 & 1.73 \\
\hline \multirow{2}{*}{$\begin{array}{l}\text { Perde devrilme momentleri toplamının yap } 1 \\
\text { devrilme momentine oran } 1 \alpha_{s}\end{array}$} & Düzenli Yapı & 0.39 \\
\hline & Düzensiz Yap1 & 0.30 \\
\hline
\end{tabular}

Düzensiz yapıda burulma momentleri aynı eksen üzerinde bulunan perdelerin zayıf doğrultularında kuvvet çiftleri oluşturmaktadır. Perdelerin düzlem dişı eğilme rijitliği, düzlem içi eğilme rijitliğine oranla çok düşük kaldığından zayıf doğrultuda oluşan kuvvet çiftleri düzensiz yapıdaki taban burulma momentlerinin perdeler tarafından yeterince karşılanamamasına sebebiyet vermektedir. Bunun bir sonucu olarak kolon ve döşemenin oluşturduğu çerçeve sistemine aktarılan kesme kuvvetleri artmıştır. Bu durumda düzensiz yapıda perde devrilme momentleri toplamının yapı toplam devrilme momentine oranı düzenli yapıya göre daha düşük olmuş ve perdelerin bulunduğu eksenden uzaklaştıkça deprem yüklerinin kolon ve döşeme sistemine aktarıldığı görülmüştür. $\mathrm{Bu}$ nedenle kirişsiz döşemelerde üst ve alt donatı ihtiyacı düzensiz yapıda düzenli yapıya kıyasla daha fazla olmaktadır. Hesap kolaylığı açısından en fazla donatı talebi belirlenmiş ve bütün döşemede belirlenen donatılar kullanılmıştır (Şekil 1 ve 2).

\section{ARTIMSAL ITTME ANALIZİ}

Düzenli ve düzensiz yapıların deprem performansı artımsal itme analizi yöntemi kullanılarak değerlendirilmiştir. Sabit yük etkisi (G) ve hareketli yük etkisi (Q) taşıyıcı sisteme doğrusal olmayan statik hesap ile artımsal olarak uygulanmıştır. Bu hesaptan elde edilen iç kuvvetler yatay deprem hesabında başlangıç değerleri olarak göz önüne alınmıştır. Beton gerilme-birim şekil değiştirme bağıntıları için TBDY [11]' de belirtilen Mander modeli, donatı çeliği gerilme-birim şekil değiştirme bağıntıları için ise Park modeli kullanılmıştır.

Betonarme kirişsiz döşemelerin doğrusal olmayan davranışının incelenebilmesi için döşemeler eşdeğer çerçeve yöntemine [16] göre eşdeğer kirişler olarak idealleştirilmiştir. Betonarme kolonlar ve eşdeğer döşeme kirişleri tek eksenli çubuk elemanlar olarak modellenmiştir. Kolon-kiriş birleşim bölgeleri rijit kabul edilmiş, kayma şekil değiştirmeleri göz önüne alınmamıştır. Betonarme perdeler kabuk sonlu elemanlar ile modellenmiştir. 
Betonarme kolon ve kirişlerin doğrusal olmayan davranış modeli için kesit içindeki beton ve donatı çubuklarına ait liflerin doğrusal olmayan eksenel gerilme-birim şekil değiştirme bağıntıları ile modellendiği lif (fiber) eleman modelleri kullanılmıştır. Lif eleman modelinde plastik şekildeğiştirme bölgesi kolon-kiriş elemanının her iki ucunda tanımlanmış ve iki plastik şekildeğiştirme bölgesi arasında kalan kısım elastik eleman olarak kabul edilmiştir. Plastik şekil değiştirme bölgesinin boyu $\left(\mathrm{L}_{\mathrm{p}}\right)$ çalışan doğrultudaki kesit boyutunun (h) yarısı olarak alınmıştır [11]. Integrasyon noktası plastik şekil değiştirme bölgesinin ortasında alınmakta ve doğrusal olmayan davranış plastik şekildeğiştirme bölgesi ile sınırlı kalmaktadır. Bu durumda doğrusal olmayan şekil değiştirmeler eleman boyunca değil plastik mafsal uzunluğu boyunca yayılı (eleman plastik bölgelerinde sınırlı) tarif edilmektedir. Plastik şekildeğiştirme bölgesindeki kesit davranışı her bir life ait gerilme-birim şekil değiştirme bağıntısının toplanması ile elde edilmektedir. Bu yöntemde kesit üzerindeki üç boyutlu eksenel kuvvet ve eğilme momenti ilişkisi doğrudan modellenebilmektedir [22]. Kesit davranışı gerilme-birim şekil değiştirme bağıntılarından elde edildiği için kesite ait moment-eğrilik ilişkisinin önceden elde edilmesine gerek yoktur. TBDY [11]' de performans hedefleri dış liflerdeki birim şekil değiştirme $\left(\varepsilon_{\mathrm{s}}\right.$ ve $\left.\varepsilon_{\mathrm{c}}\right)$ sınırları dikkate alınarak verilmiştir. Lif eleman modelinde bu değerler doğrudan elde edilmektedir.

Betonarme perdelerde kolon-kiriş elemanlarında olduğu gibi kesit içindeki beton ve donatı çubuklarına ait liflerin, doğrusal olmayan eksenel gerilme-birim şekil değiştirme bağıntıları ile modellendiği lif (fiber) eleman modelleri kullanılmıştır. Eksenel kuvvet/eğilme etkileri her bir life ait gerilme-birim şekil değiştirme bağıntısının toplanması ile elde edilmektedir. Kesme kuvveti etkileri lif elemanlar ile etkileşimsiz ve doğrusal kabul edilmektedir. Plastik şekildeğiştirme bölgesi boyu kabuk eleman yüksekliğinde alınmakta ve integrasyon noktası kabuk elemanın orta noktasında tanımlanmaktadır. Sayısal model oluşturulurken perde elemanlar her biri kat yüksekliğinin yarısı yükseklikte olmak üzere her katta iki kabuk eleman ile tanımlanmıştır. Bu durumda doğrusal olmayan şekil değiştirmeler elemanın uzunluğu boyunca sürekli (yayılı) biçimde göz önüne alındığından ayrıca eleman üzerinde etkin eğilme rijitliği tanımı yapılmamıştır.

Artımsal itme analizinde düzenli yapıda hakim doğal titreşim mod şekli genliği ile orantılı yatay yük dağılımı kullanılmıştır. Düzensiz yapıda hakim titreşim moduna ait etkin kütle oran $1 \% 70$ 'in altında kalmaktadır. Düzensiz yapıda burulma modlarının katkılarını da dikkate alabilmek amacıyla artımsal itme analizinin zaman tanım aralığında (quasi-static) çözümlemesi yapılmıştır [21].

$\mathrm{Bu}$ yöntemde yapının hareket denklemi, önceden belirlenmiş bir şablona göre uygulanmış yükler altında çözümlenmektedir.

$$
\mathbf{M} \ddot{\mathbf{X}}(t)+\mathbf{C} \dot{\mathbf{X}}(t)+\mathbf{K X}(t)=\lambda(t) \mathbf{P}_{\mathbf{o}}
$$

Hareket denkleminde $\mathrm{X}$ yerdeğiştirme vektörünü, $\mathrm{P}_{0}$ nominal yük vektörünü, $\lambda(\mathrm{t})$ tırmanma (ramp) fonksiyonunu, $\mathrm{M}$ kütle matrisini, $\mathrm{C}$ sönüm matrisini ve $\mathrm{K}$ rijitlik matrisini göstermektedir. Zorlanmış titreşimin sükunetten başladığı kabul edilerek zorlama, tırmanma (ramp) fonksiyonu ile zaman içerisinde artımsal olarak uygulanmakta ve çözümleme kontrol noktasındaki yerdeğiştirme önceden belirlenen değerine ulaşıncaya kadar sürdürülmektedir. Tırmanma fonksiyonunun son değerine ulaşıncaya kadar geçen süre olarak tanımlanan 
yükselme zamanı, yapının doğal titreşim periyoduna göre çok küçük alınır ise yapı darbe (impuls) yük etkisine benzer bir yapı cevabı gösterecektir. Öte yandan yapının doğal titreşim periyodundan çok büyük yükselme zamanı alınır ise (oldukça yavaş artan yükleme durumu) dinamik titreşimler küçük ve yapı cevabı statik çözüme yakın olacaktır [23]. Quasi-statik çözümlemede yük artım zaman aralığı 1 sn olarak alınmış ve belirlenen tepe yerdeğiştirme değerine ulaşana kadar dinamik çözümleme yapılmıştır. $\mathrm{P}_{0}$ nominal yük vektörü belirlenirken birinci mod şekline göre hesaplanan kat kuvvetleri yerine, kat kütlelerinin dağılımı ile orantılı bir yük vektörü dikkate alınmıştır.

Artımsal itme analizi sonucunda Y-Y doğrultusu taban kesme kuvveti ve Y-Y doğrultusu tepe yerdeğiştirmelerinin çizildiği itme eğrileri elde edilmiş ve itme eğrileri modal kapasite diyagramlarına dönüştürülmüştür. Modal kapasite eğrileri üzerinde hasar sınırlarının belirlenebilmesi için modal kapasite eğrileri elasto-plastik diyagram ile idealleştirilmiştir. İdealleştirilme işleminde diyagramların altında kalan alanların eşitliği esas alınmıştır. Sınır hasar seviyeleri oluşturulmuş modal kapasite diyagramları üzerinden tanımlanmıştır. Modal kapasite diyagramının doğrusallıktan ayrıldığı noktadaki modal yerdeğiştirme değeri Hafif Hasar sınırı olarak belirlenmiştir. Elastik rijitliği ve elastik ötesi rijitliği temsil eden iki doğru parçasının kesiştiği noktadaki modal yerdeğiştirme değeri Orta Hasar sınırı olarak belirlenmiştir. Göçme sınırı ise modal kapasite diyagramındaki modal ivmenin \%5'den daha fazla azaldığı ilk modal yerdeğiştirme seviyesi olarak belirlenmiştir. Orta Hasar sınırı ile Göçme sınırı arasındaki bölgenin ortası İleri Hasar sınırı olarak belirlenmiştir [24]. Düzenli ve düzenli olmayan yapılara ait modal kapasite diyagramları sırasıyla Şekil 4 ve Şekil 5'de gösterilmiştir.

Yapıların yatay yerdeğiştirme cinsinden süneklik kapasiteleri $\left(\mu=\delta_{\mathrm{u}} / \delta_{\mathrm{y}}\right)$ düzenli yap1 için 4.01, düzensiz yapı için 2.81 hesaplanmıştır. Burada $\delta_{\mathrm{y}}$ orta hasar yerdeğiştirme değerine, $\delta_{\mathrm{u}}$ göçme sınırı yerdeğiştirme değerine karşılık gelmektedir. $\delta_{\mathrm{y}}$ değerine karşılık gelen öteleme oranı düzenli yapıda $\% 0.85$, düzensiz yapıda $\% 0.72$ olarak hesaplanmıştır. $\delta_{\text {u }}$ değerine karşı1ık gelen öteleme oranı düzenli yapıda $\% 3.4$, düzensiz yapıda $\% 2$ olarak hesaplanmıştır. Dayanım fazlalığı katsayısı $\left(\mathrm{D}=\mathrm{f}_{\mathrm{y}} / \mathrm{f}_{\mathrm{d}}\right)$ düzenli yap1 için 1.54 , düzensiz yap1 için 1.51 hesaplanmıştır. Burada $f_{y}$ yapının orta hasar sınırına karşılık gelen dayanımına, $f_{d}$ yapının hafif hasar sınırına karşılık gelen dayanımına karşılık gelmektedir. Buna göre deprem yükü azaltma katsayısı $(\mathrm{R}=\mu \mathrm{x} \mathrm{D})$ düzenli yap1 için 6.17 , düzensiz yap1 için 4.23 hesaplanabilir. Görüldüğü gibi perdeler planda burulma düzensizliği yaratmayacak şekilde yerleştirildiğinde deprem yükü azaltma katsayısı TBDY [11]' de önerilen değeri sağlamaktadır. Perdelerin planda burulma düzensizliği yaratacak şekilde yerleştirilmesi durumunda ise yapının süneklik düzeyi sınırlı bir sistem gibi davrandığı anlaşılmaktadır. Buradan kirişsiz döşemeli sitemlerin süneklik düzeyi yüksek perdeler ile birlikte kullanıldığında, TBDY [11]'de verilen perde koşulları yerine getirilse bile perdelerin plandaki yerleşimlerine dikkat edilmediğinde yapının sünekliğinin hedeflenen seviyelerde olamayabileceği görülmektedir.

Modal kapasite diyagramlarında farklı hasar sınırlarına karşılık gelen plastik mafsal oluşumları elde edilmiş ve hesaplanan değerler kolon, perde ve eşdeğer döşeme kirişleri için ayrı ayrı Tablo 2'de verilmiştir.

Hafif hasar seviyesinde hem düzenli yapıda hem de düzensiz yapıda 1. kat kolonlarının alt uçlarında plastik mafsal oluşumu gözlemlenmiştir. Düzenli yapıda ayrıca eşdeğer döşeme kirişlerinin perdelere bağlandığı noktalarda ve perdelerin kritik perde bölgelerinde plastik 
mafsallar oluşmuştur. Plastik mafsal oluşan kesitlerdeki en dış liflerdeki birim uzamaların kontrollü hasar sınırını $(\mathrm{KH})$ aşmadığı tespit edilmiştir.

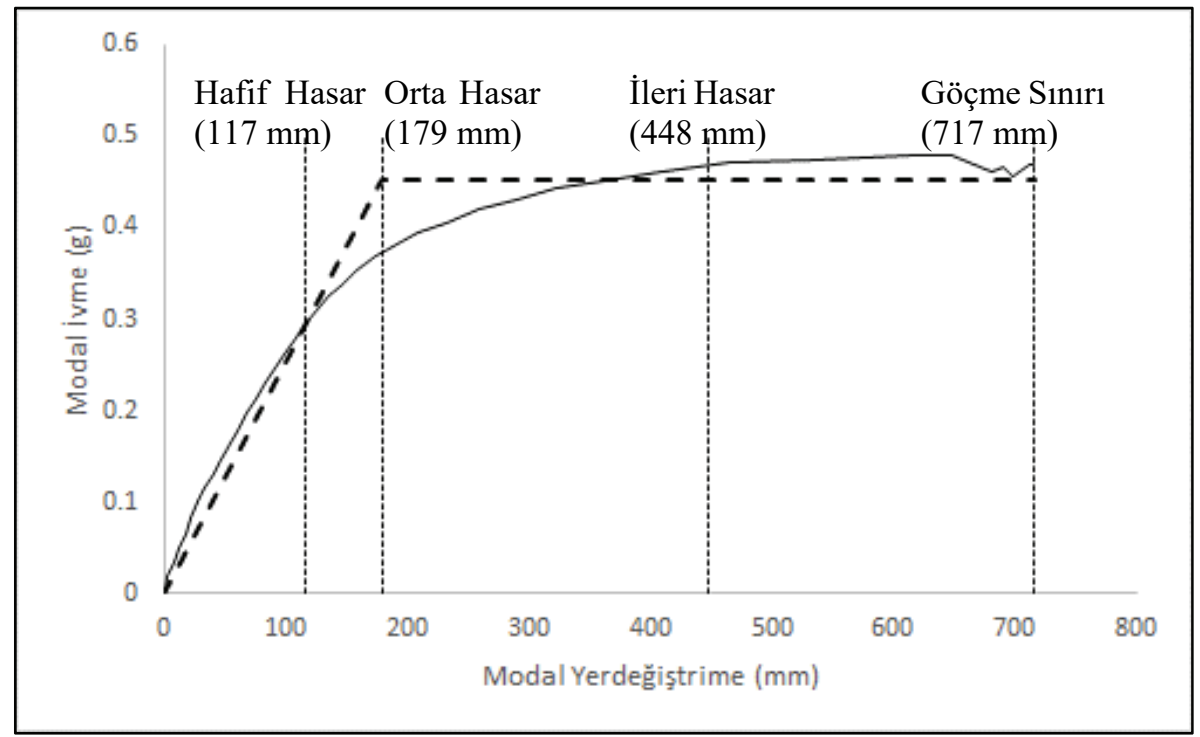

Şekil 4 - Düzenli yapıya ait modal kapasite diyagramı

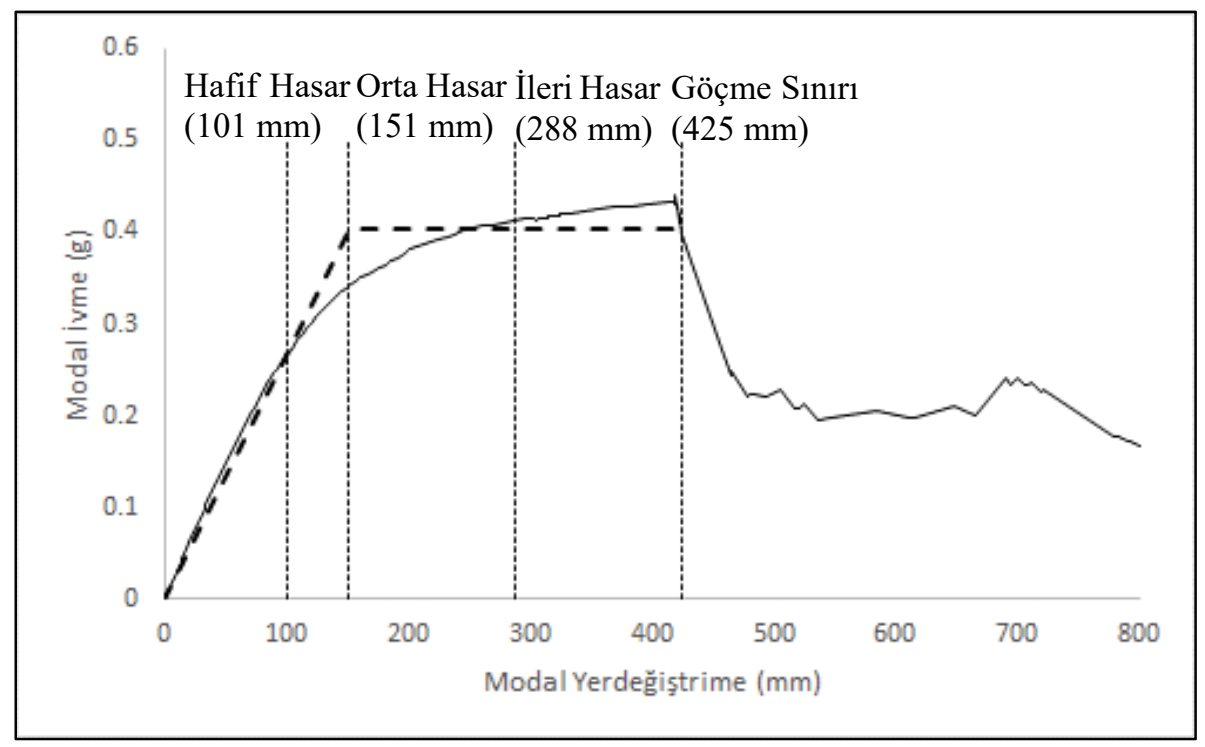

Şekil 5 - Düzensiz yapıya ait modal kapasite diyagramı 
Orta hasar seviyesinde hem düzenli hem de düzensiz yapıda kolonlardaki mafsal oluşumlarının üst katlara doğru yayıldığı gözlemlenmiştir. Düzenli yapıda perdelerin bulunduğu 1 ve 5 eksenlerinde kolonlara bağlanan eşdeğer döşeme kirişlerinde KH sınırını aşmayan plastik mafsal oluşumları görülmüştür. Eşdeğer döşeme kirişlerinin perdelere bağlandığı noktalarda hafif hasar seviyesinde gözlemlenmiş olan plastik mafsalların orta hasar seviyesinde 2. ve 3. katlarda KH sınırını aştığı tespit edilmiştir. Düzensiz yapıda plastik mafsalların 5 ve 4 eksenlerinde kolonlara bağlanan eşdeğer döşeme kirişlerinde oluştuğu gözlemlenmiştir. Plastik mafsal oluşan kesitlerdeki en diş liflerdeki birim uzamaların $\mathrm{KH}$ sınırını aşmadığı tespit edilmiştir.

İleri hasar seviyesinde eşdeğer döşeme kirişlerinde çok sayıda plastik mafsal oluşumu gözlemlenmiştir. Eşdeğer döşeme kirişlerinin hemen hepsinde sınırlı hasar (SH) sınırının birçoğunda ise KH sınırının aşıldığ 1 görülmektedir. Ayrıca düzenli yapıda göçmenin önlenmesi performans (GÖ) sınırı 1 ve 5 eksenlerindeki perdelere bağlanan eşdeğer döşeme kirişlerinde aşılmıştır. Düzenli ve düzensiz yapıda 1. kat kolonlarının alt uçlarında GÖ sınırının aşıldığı kesit zorlanmaları görülmektedir.

Tablo 2 - Yapı Hasar Seviyelerine Karşılık Gelen Plastik Mafsal Oluşumları

\begin{tabular}{|c|c|c|c|c|c|c|c|c|}
\hline \multirow{2}{*}{$\begin{array}{l}\text { Hasar } \\
\text { Seviyesi }\end{array}$} & \multirow{2}{*}{$\begin{array}{l}\text { Betonarme } \\
\text { Eleman }\end{array}$} & \multicolumn{3}{|c|}{ Düzenli Yapı } & \multicolumn{3}{|c|}{ Düzensiz Yap1 } & \multirow[b]{2}{*}{ Toplam } \\
\hline & & $\begin{array}{l}\mathrm{SH}- \\
\mathrm{KH}\end{array}$ & $\begin{array}{l}\text { KH- } \\
\text { GÖ }\end{array}$ & $>$ GÖ & $\begin{array}{l}\text { SH- } \\
\mathrm{KH}\end{array}$ & $\begin{array}{l}\text { KH- } \\
\text { GÖ }\end{array}$ & $>\mathrm{GÖ}$ & \\
\hline \multirow{3}{*}{$\begin{array}{l}\text { Hafif } \\
\text { Hasar }\end{array}$} & Kolon & 6 & 0 & 0 & 11 & 0 & 0 & 224 \\
\hline & Perde & 2 & 0 & 0 & 0 & 0 & 0 & 28 \\
\hline & $\begin{array}{l}\text { Eşdeğer } \\
\text { Döşeme K. }\end{array}$ & 8 & 0 & 0 & 0 & 0 & 0 & 434 \\
\hline \multirow{3}{*}{$\begin{array}{l}\text { Orta } \\
\text { Hasar }\end{array}$} & Kolon & 28 & 0 & 0 & 19 & 0 & 0 & 224 \\
\hline & Perde & 2 & 0 & 0 & 0 & 0 & 0 & 28 \\
\hline & $\begin{array}{l}\text { Eşdeğer } \\
\text { Döşeme K. }\end{array}$ & 18 & 4 & 0 & 10 & 0 & 0 & 434 \\
\hline \multirow{3}{*}{$\begin{array}{l}\text { İleri } \\
\text { Hasar }\end{array}$} & Kolon & 39 & 26 & 6 & 21 & 3 & 12 & 224 \\
\hline & Perde & 4 & 0 & 0 & 3 & 0 & 0 & 28 \\
\hline & $\begin{array}{l}\text { Eşdeğer } \\
\text { Döşeme K. }\end{array}$ & 54 & 94 & 14 & 70 & 22 & 0 & 434 \\
\hline \multirow{3}{*}{$\begin{array}{c}\text { Göçme } \\
\text { Sinırı }\end{array}$} & Kolon & 52 & 14 & 28 & 92 & 0 & 16 & 224 \\
\hline & Perde & 0 & 4 & 0 & 3 & 0 & 0 & 28 \\
\hline & $\begin{array}{l}\text { Eşdeğer } \\
\text { Döşeme K. }\end{array}$ & 14 & 82 & 89 & 36 & 90 & 14 & 434 \\
\hline
\end{tabular}

SH: Sınırlı Hasar, KH: Kontrollü Hasar, GÖ: Göçmenin Önlenmesi Performans Düzeyleri 
Göçme sınırı seviyesinde düzensiz yapıda 4 ve 5 eksenlerinde bütün kolon ve eşdeğer döşeme kirişlerinin mafsallaştığı mekanizma durumu gözlemlenmektedir. Bu eksenlerde özellikle 1. ve 2. kat kolon ve eşdeğer döşeme kirişlerinde GÖ sınırının aşıldığı kesit zorlanmaları tespit edilmiştir. Düzenli yapıda benzer şekilde eşdeğer döşeme kirişi-kolon çerçeve sisteminde mekanizma durumu gözlemlenmiştir Eşdeğer döşeme kirişlerinin büyük çoğunluğunda ve alt kat kolonlarında GÖ sınırının aşıldığı kesit zorlanmaları tespit edilmiştir. Betonarme perdelerde kritik perde yüksekliği boyunca oluşan plastik mafsallar GÖ sınırını aşmamıştır ve planda simetrik olarak yerleştirilmiş perdeler düzensiz yapıdan farklı olarak yapının yanal stabilitesini sağlamaktadır.

Modal kapasite diyagramları incelendiğinde, modal yerdeğiştirme talebi düzenli yapı için ileri hasar seviyesindeyken bu değer düzensiz yapı için göçme sınırına karşılık gelmektedir. Buradan hareketle düzenli yapıda ileri hasar ve düzensiz yapıda göçme sınırı hasar seviyeleri karşılaştırıldığında, eşdeğer döşeme kirişlerindeki ve kolonlardaki mafsal oluşumlarının sayı ve dağılım olarak benzer olduğu görülmektedir. Temel fark perdelerin plandaki yerleşiminden kaynaklanmıştır. Düzenli yapıda betonarme perdeler, eşdeğer döşeme kirişi ve kolonların oluşturduğu çerçevelerde meydana gelen plastik mafsallar neticesinde oluşan yanal rijitlik ve dayanım kayıplarını üstlenilebilmiştir. Öte yandan düzensiz yapıda betonarme perdelerin burulma rijitliğine katkısı sınırlıdır ve bu sebeple perde ekseninden uzaklaşan eksenlerdeki rijitlik ve dayanım kayıpları telafi edilememiştir. Düzensiz yapı göçme sınırına geldiğinde perdelerden birinde plastik mafsal oluşmamış, diğer perdelerde ise oluşan plastik mafsallar KH sınırını aşmamıştır. Bu durum analizin sonlandığı noktaya kadar değişmemiştir.

\section{ZAMAN TANIM ARALIĞINDA ANALIZLER}

Çalışmada kullanılan düzenli ve düzensiz yapıların performansları doğrusal elastik olmayan davranış gözönüne alınarak zaman tanım aralığında analizler ile irdelenmiştir. Analizlerde kullanılan güçlü yer hareketi kayıtları Pacific Earthquake Engineering Research Center veri tabanından [25] elde edilmiş ve güçlü yer hareketi kayıtlarının genlikleri tasarım ivme spektrumu ile uyuşacak şekilde ölçeklendirilmiştir. Seçilen ve ölçeklenmiş güçlü yer hareketi kayıtlarına ait detaylı bilgiler Tablo 3'de ve ölçeklenmiş her kayıta ait tepki spektrumları Şekil 6'da verilmiştir.

Her bir deprem durumuna karşılık gelen en büyük tepe yerdeğiştirmeleri ve göreli kat ötelenmeleri elde edilmiştir. Bütün deprem durumları için düzensiz yapıda en büyük tepe yerdeğiştirmesi taleplerinin düzenli yapıya kıyasla daha büyük olduğu görülmektedir. Tepe yerdeğiştirmeleri arasındaki bu fark Chi Chi depremi için \%95 (Şekil 7), Kobe depremi için \%45 (Şekil 9), Northridge depremi için \%93 (Şekil 11), Loma Prieta depremi için \%51 (Şekil 13), ve Kocaeli depremi için \%85 (Şekil 15) olarak hesaplanmıştır. Göreli kat ötelenmesi taleplerinin düzensiz yapıda, düzenli yapıya kıyasla Chi Chi depremi için \%51 (Şekil 8), Kobe depremi için \%25 (Şekil 10), Northridge depremi için \%105 (Şekil 12), Loma Prieta depremi için \%74 (Şekil 14) ve Kocaeli depremi için \%107 (Şekil 16) arttığı hesaplanmıştır. Ayrıca düzenli yapıda bütün depremler için göreli kat ötelenmelerinin DBYBHY [10]'de verilen 0.02 ve TBDY [11]'de verilen 0.008 x DD-2 / DD-3 (yaklaşık olarak 0.02) sınır değerlerini aşmadığı tespit edilmiştir. Öte yandan düzensiz yapıda Loma Prieta, Northridge ve Kocaeli depremlerinde göreli kat ötelenmesi sınır değerinin aşıldığı görülmektedir. 


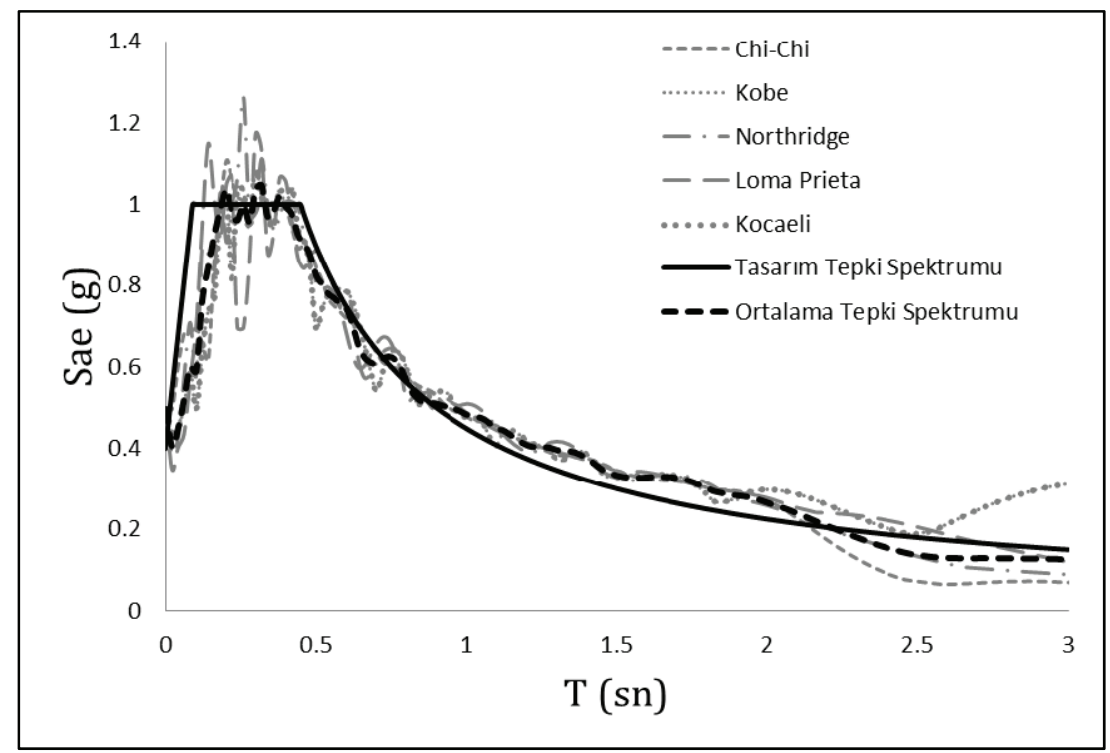

Şekil 6 - Kuvvetli yer hareketleri tepki spektrumları

Tablo 3 - Çalışmada kullanılan kuvvetli yer hareketleri

\begin{tabular}{|l|l|l|l|l|l|l|l|}
\hline \multirow{2}{*}{ Kayıt } & \multirow{2}{*}{ İstasyon } & \multirow{2}{*}{ Y1lı } & Şiddeti & \multicolumn{2}{|c|}{ Orjinal } & \multicolumn{2}{c|}{ Ölçekli } \\
\cline { 5 - 8 } & & & & $\begin{array}{l}\text { PGA } \\
(\mathrm{g})\end{array}$ & $\begin{array}{l}\text { PGV } \\
(\mathrm{mm} / \mathrm{s})\end{array}$ & $\begin{array}{l}\text { PGA } \\
(\mathrm{g})\end{array}$ & $\begin{array}{l}\text { PGV } \\
(\mathrm{mm} / \mathrm{s})\end{array}$ \\
\hline Chi-Chi & TCU045 & 1999 & 7.62 & 0.361 & 215.48 & 0.498 & 484.33 \\
\hline Kobe & CUE90 & 1995 & 6.9 & 0.345 & 276.78 & 0.349 & 276.39 \\
\hline Northridge & CDMG090 & 1994 & 6.69 & 0.568 & 518.27 & 0.370 & 438.46 \\
\hline Loma Prieta & CDMG090 & 1989 & 6.93 & 0.367 & 446.95 & 0.344 & 467.54 \\
\hline Kocaeli & KOERI330 & 1999 & 7.51 & 0.349 & 621.82 & 0.438 & 589.72 \\
\hline
\end{tabular}

DBYBHY [10] ve TBDY [11]'de kirişsiz döşemeli sistemlerin süneklik düzeyi sınırlı sistemler olarak dikkate alınması öngörülmektedir. Kirişsiz döşemeli sistemlerde oluşabilecek şekildeğiştirmeleri sınırlamak için betonarme perde kullanımı zorunlu kılınmıştır. Fakat zaman tanım aralığında doğrusal olmayan analizler neticesinde plandaki yerleşimlerine dikkat edilmediği takdirde perdelerin, şekildeğiştirme taleplerini sınırlamak hususunda yetersiz kalabileceği görülmektedir.

Her bir deprem durumuna karşılık gelen plastik mafsal oluşumları elde edilmiş, kolon, perde ve eşdeğer döşeme kirişleri için ayrı ayrı Tablo 4'de verilmiştir. DD-2 Düzeyine ölçeklenmiş deprem yer hareketleri altında düzenli yapıda kontrollü hasar performans seviyesini aşan yapısal eleman bulunmamaktadır. Düzenli yapıda kontrollü hasar performans hedefine ulaşılmıştır. 
Tablo 4 - DD-2 Düzeyi Deprem Yer Hareketlerine Karşılık Gelen Plastik Mafsal Oluşumları

\begin{tabular}{|c|c|c|c|c|c|c|c|c|}
\hline \multirow{2}{*}{$\begin{array}{l}\text { Güçlü Yer } \\
\text { Hareketi }\end{array}$} & \multirow{2}{*}{$\begin{array}{l}\text { Betonarme } \\
\text { Eleman }\end{array}$} & \multicolumn{3}{|c|}{ Düzenli Yapı } & \multicolumn{3}{|c|}{ Düzensiz Yap1 } & \multirow{2}{*}{ Toplam } \\
\hline & & SH-KH & KH-GÖ & $>\mathrm{GÖ}$ & SH-KH & KH-GÖ & $>\mathrm{GÖ}$ & \\
\hline \multirow{3}{*}{$\begin{array}{l}\text { Loma } \\
\text { Prieta }\end{array}$} & Kolon & 35 & 0 & 0 & 32 & 0 & 14 & 224 \\
\hline & Perde & 4 & 0 & 0 & 4 & 0 & 0 & 28 \\
\hline & Eşdeğer D. K. & 154 & 0 & 0 & 149 & 9 & 0 & 434 \\
\hline \multirow{3}{*}{ Northridge } & Kolon & 16 & 0 & 0 & 36 & 0 & 12 & 224 \\
\hline & Perde & 4 & 0 & 0 & 4 & 0 & 0 & 28 \\
\hline & Eşdeğer D. K. & 96 & 0 & 0 & 113 & 14 & 0 & 434 \\
\hline \multirow{3}{*}{ Kobe } & Kolon & 15 & 0 & 0 & 19 & 0 & 7 & 224 \\
\hline & Perde & 4 & 0 & 0 & 2 & 0 & 0 & 28 \\
\hline & Eşdeğer D. K. & 113 & 0 & 0 & 104 & 0 & 0 & 434 \\
\hline \multirow{3}{*}{ Chi Chi } & Kolon & 16 & 0 & 0 & 43 & 0 & 9 & 224 \\
\hline & Perde & 4 & 0 & 0 & 0 & 0 & 0 & 28 \\
\hline & Eşdeğer D. K. & 108 & 0 & 0 & 111 & 0 & 0 & 434 \\
\hline \multirow{3}{*}{ Kocaeli } & Kolon & 17 & 0 & 0 & 37 & 0 & 14 & 224 \\
\hline & Perde & 4 & 0 & 0 & 3 & 0 & 0 & 28 \\
\hline & Eşdeğer D. K. & 98 & 0 & 0 & 148 & 12 & 0 & 434 \\
\hline
\end{tabular}

SH: Sınırlı Hasar, KH: Kontrollü Hasar, GÖ: Göçmenin Önlenmesi Performans Düzeyleri

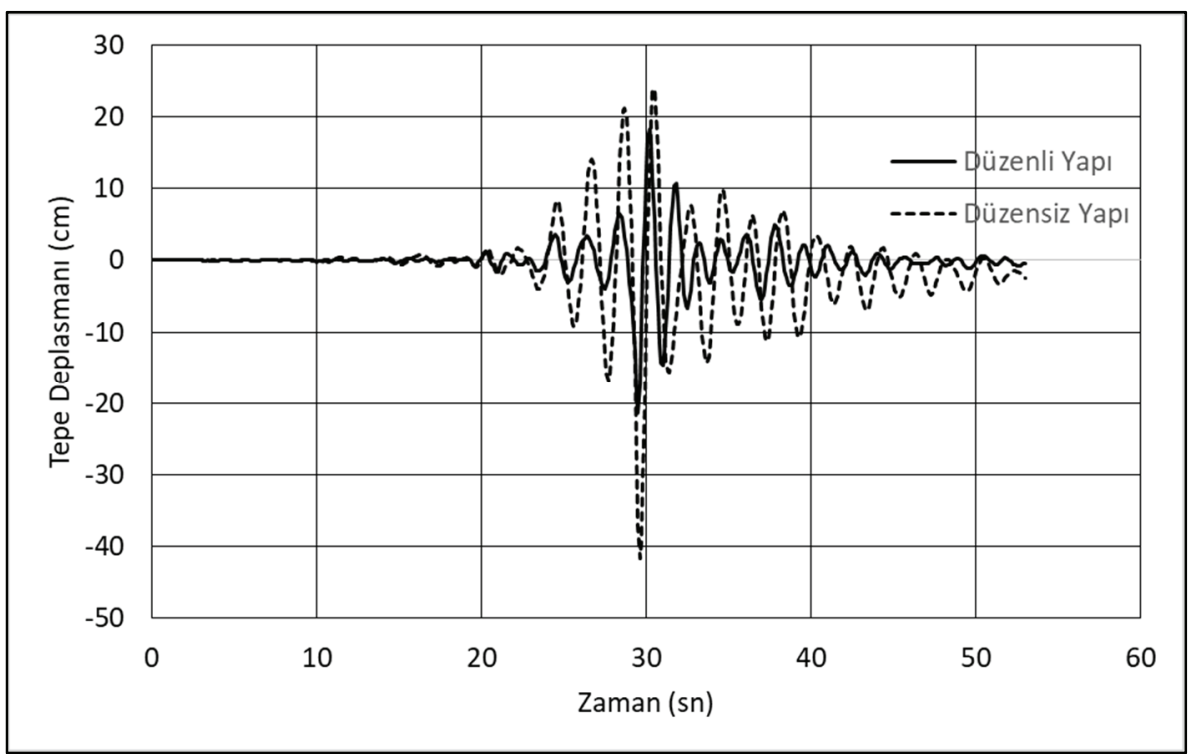

Şekil 7 - Tepe yerdeğiştirmesi - Chi Chi 
Betonarme Perdelerin Plandaki Yerleşimlerinin Kirişsiz Döşemeli Yapılara ...

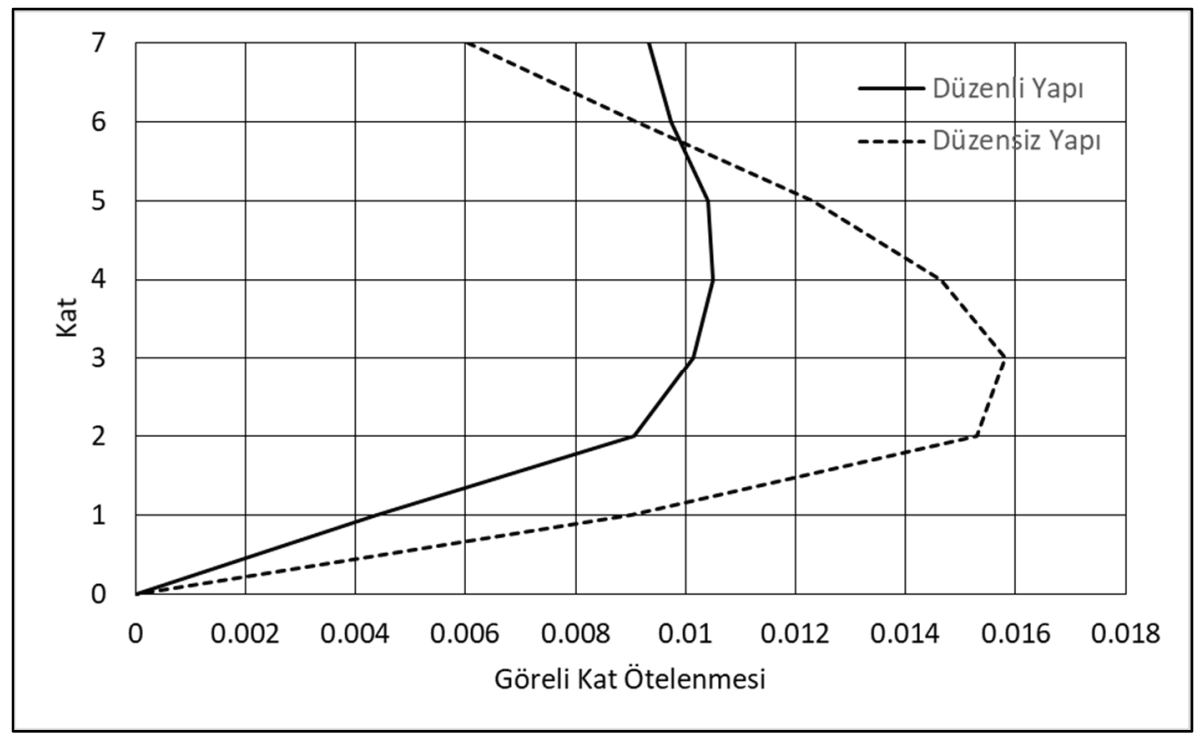

Şekil 8 - Göreli kat ötelenmesi-Chi Chi

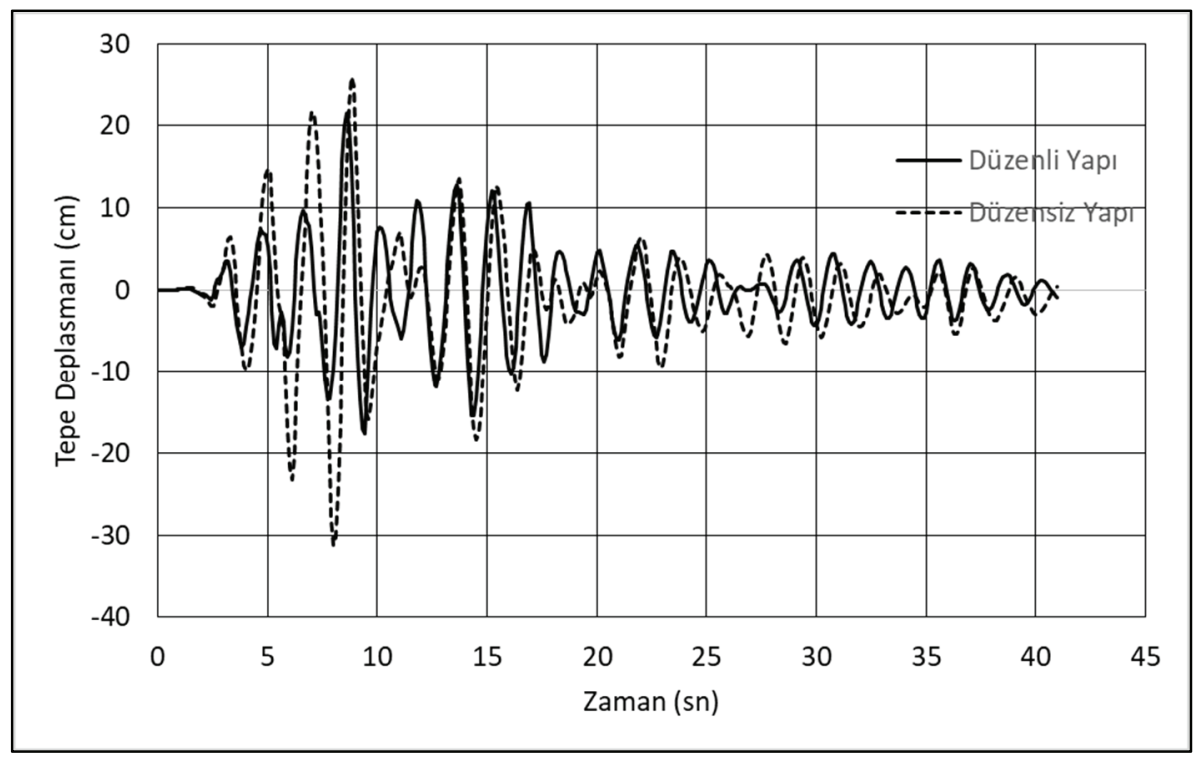

Şekil 9 - Tepe yerdeğiştirmesi - Kobe 


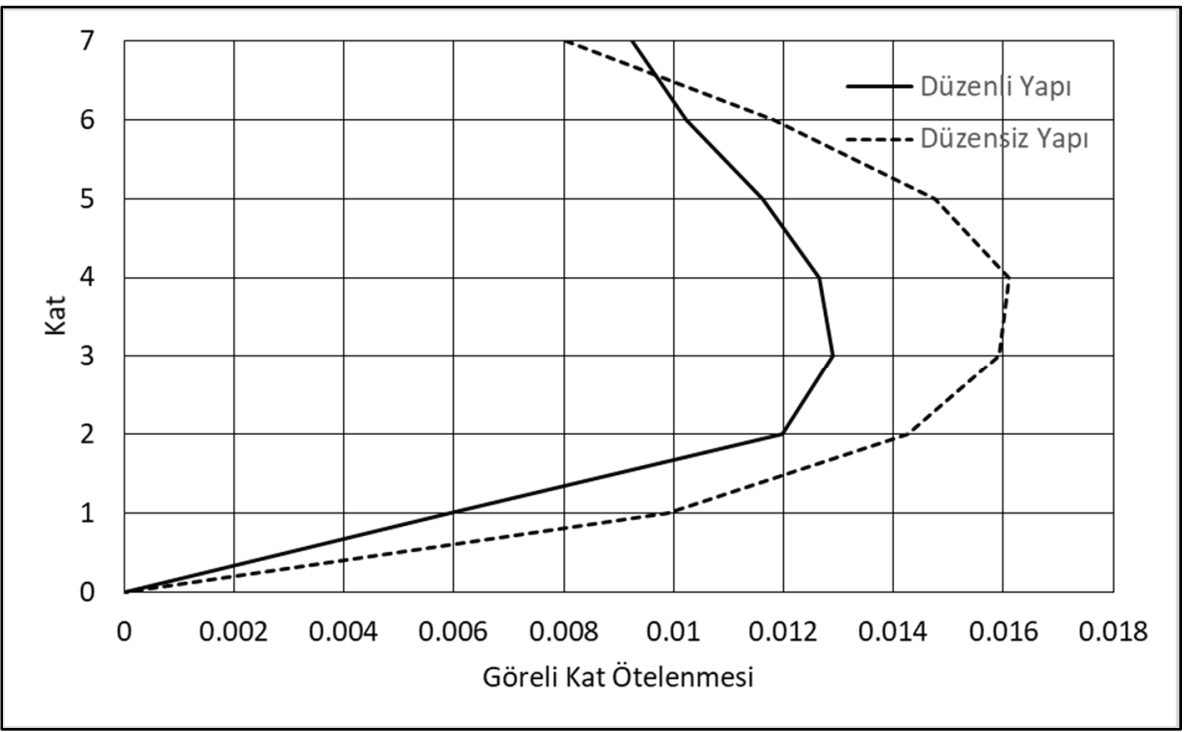

Şekil 10 - Göreli kat ötelenmesi - Kobe

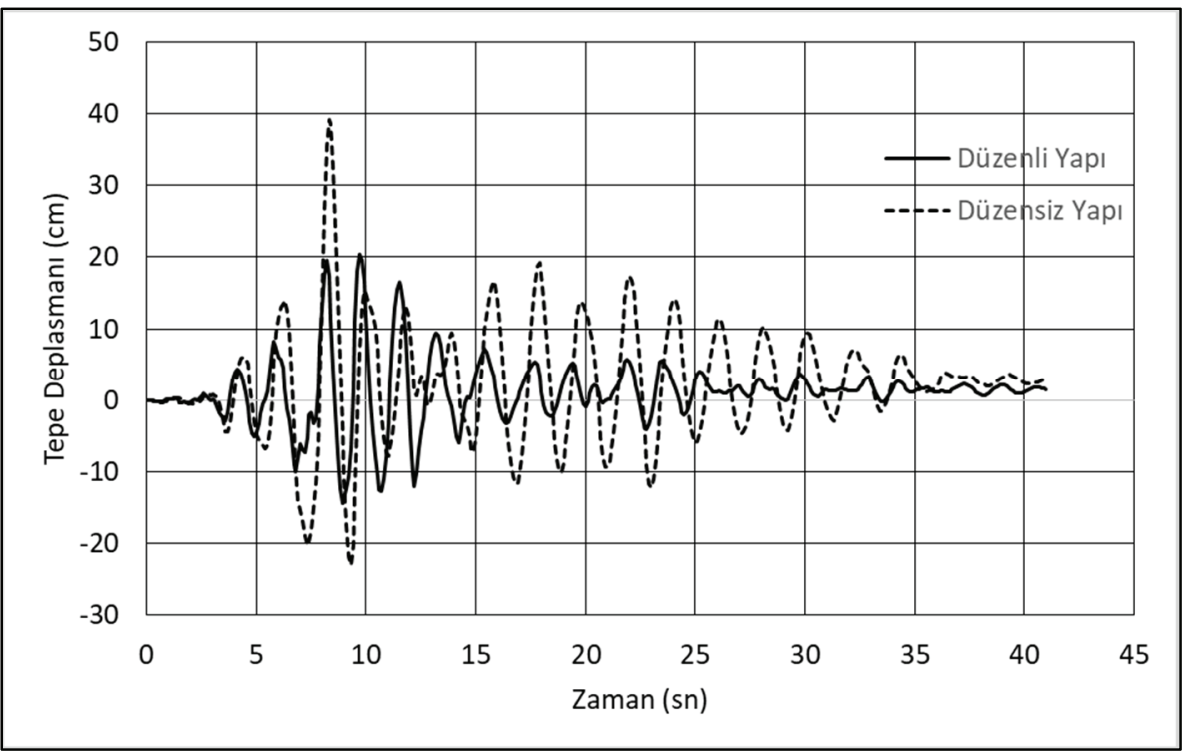

Şekil 11 - Tepe yerdeğiştirmesi - Northridge 
Betonarme Perdelerin Plandaki Yerleşimlerinin Kirişsiz Döşemeli Yapılara ...

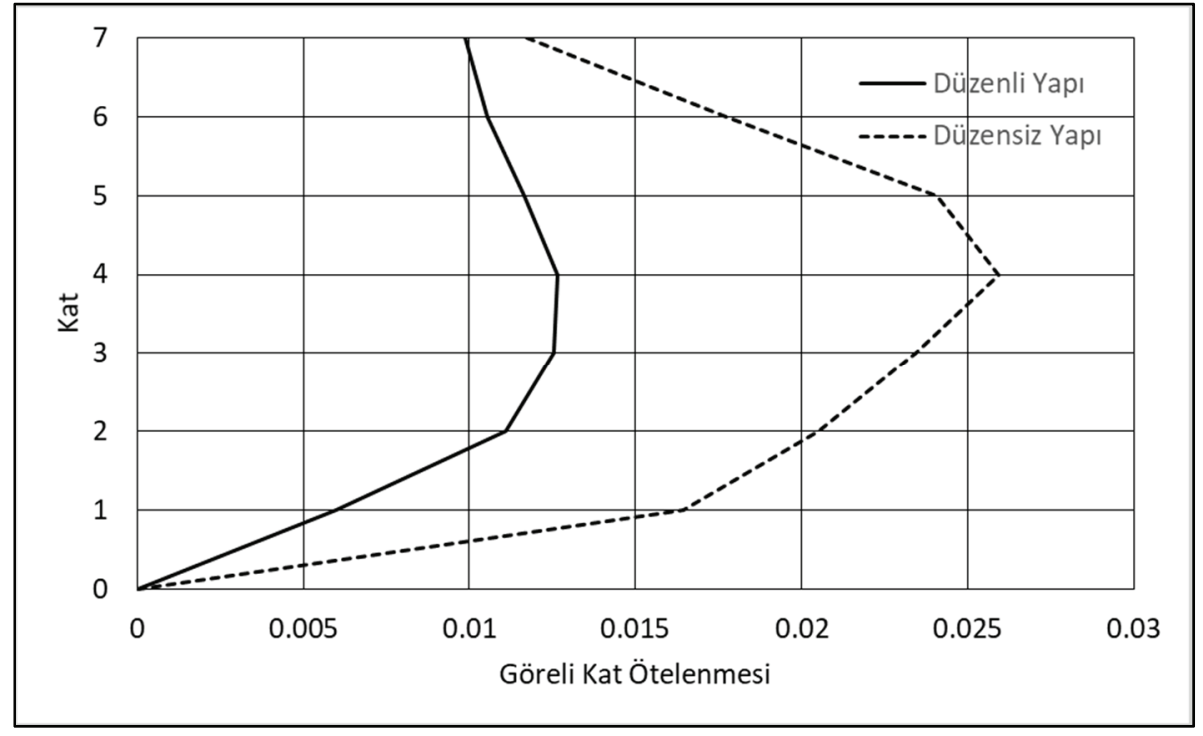

Şekil 12 - Göreli kat ötelenmesi-Northridge

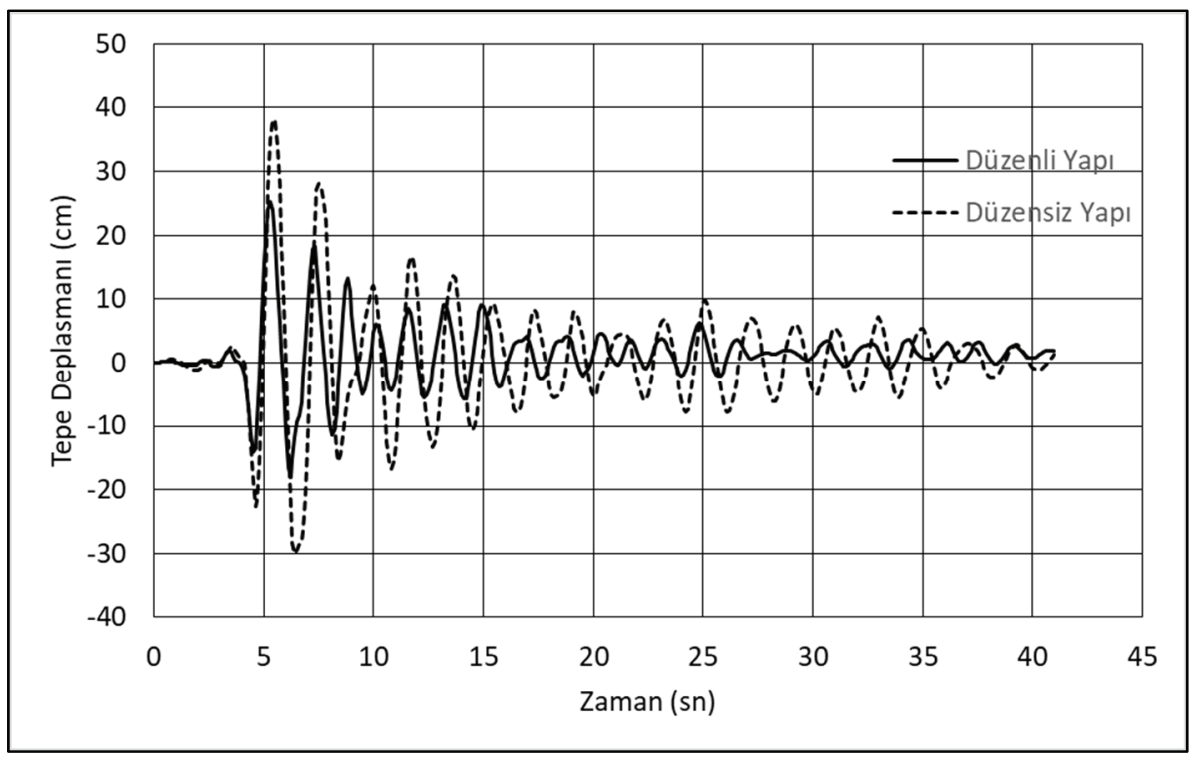

Şekil 13 - Tepe yerdeğiştirmesi - Loma Prieta 


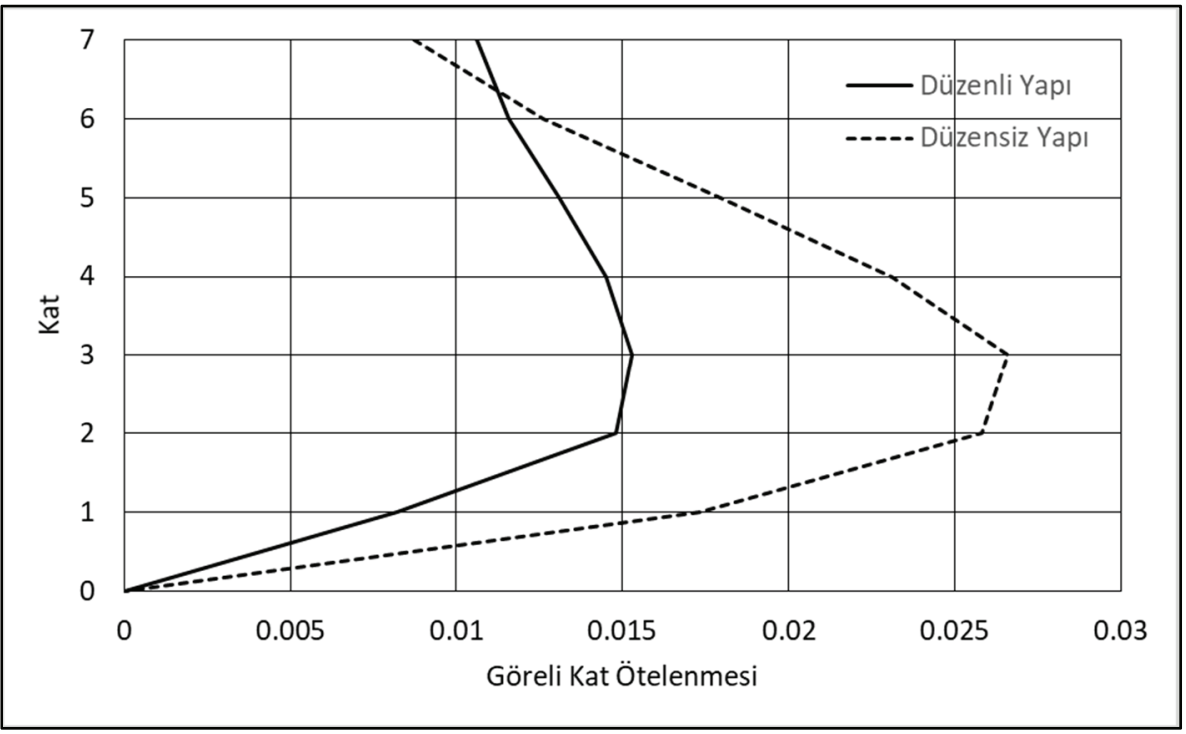

Şekil 14 - Göreli kat ötelenmesi - Loma Prieta

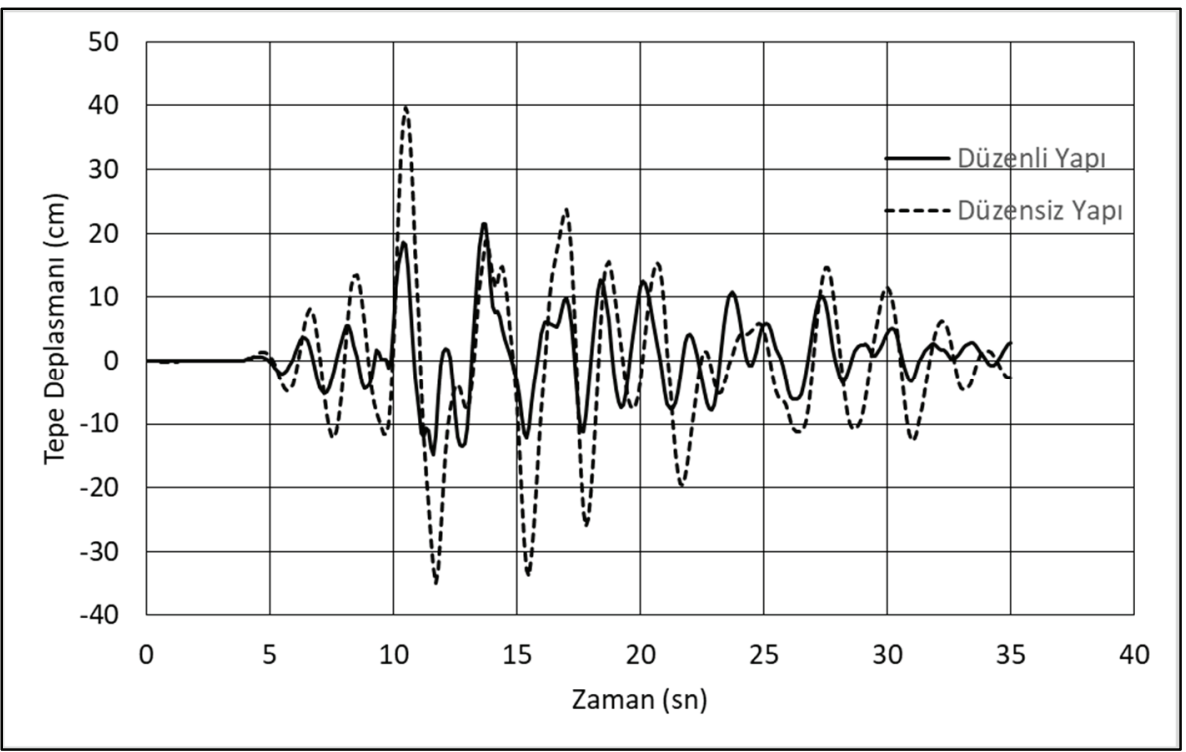

Şekil 15 - Tepe yerdeğiştirmesi - Kocaeli 


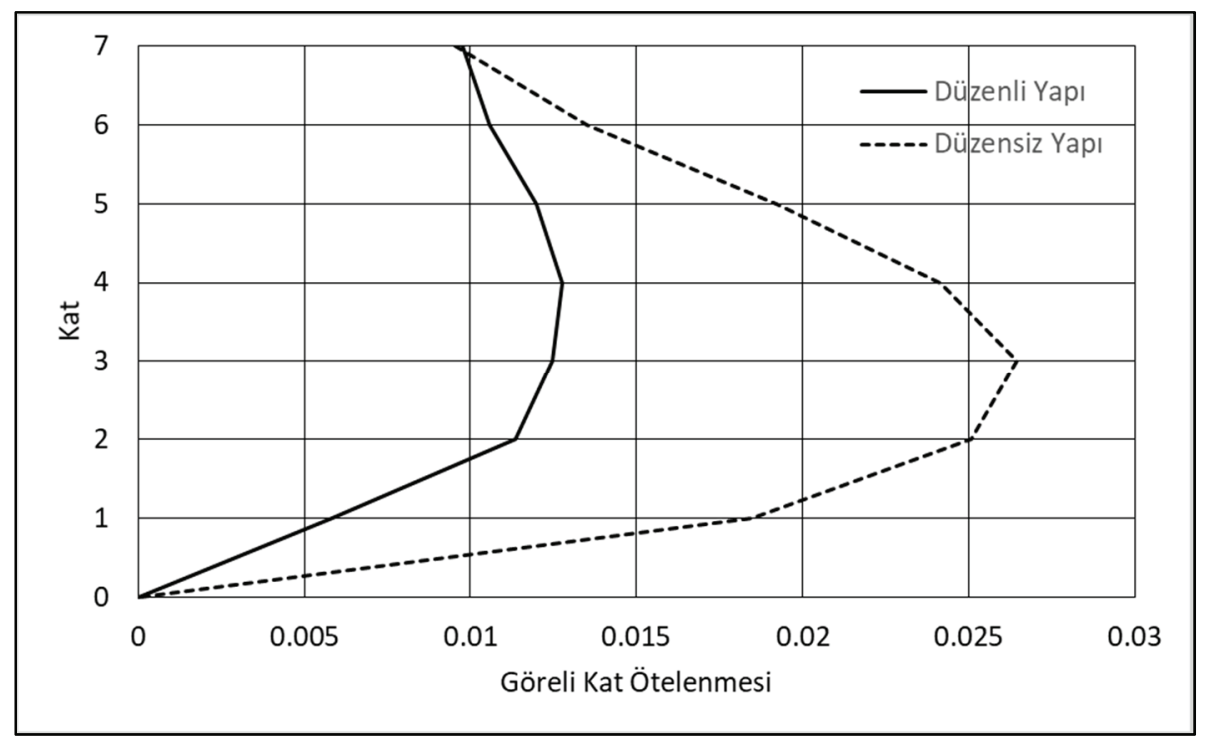

Şekil 16 - Göreli kat ötelenmesi-Kocaeli

DD-2 Düzeyine ölçeklenmiş deprem yer hareketleri altında düzensiz yapıda kontrollü hasar performans seviyesini aşan eşdeğer döşeme kirişleri bulunmaktadır. Kirişsiz döşemelerde sargı donatısı bulunmadığı için akma sonrası birim şekil değiştirme kapasitesinin oldukça sınırlı kalacağı ve buna bağlı olarak güç tükenmesin erken gerçekleşeceği beklenmelidir. Bu elemanlar tasarım yükleri altında yeterli zımbalama dayanımına sahip olacak şekilde tasarlanmalarına rağmen deprem sırasında kontrollü hasar sınırının ötesinde birim şekildeğiştirmelere maruz kaldıklarında sargısız betonda meydana gelebilecek hasarların zımbalama riski oluşturabileceği unutulmamalıdır. Düzensiz yapıda ayrıca göçmenin önlenmesi performans seviyesini aşan kolonlar bulunduğu tespit edilmiştir. Bu kolonlar yapıda burulma etkisinin en çok hissedildiği 4 ve 5 eksenlerinde konumlanmışlardır. Burulma ve ikinci mertebe etkilerine bağlı olarak bu kolonlarda özellikle alt katlarda aşırı birim şekildeğiştirmeler gözlenmektedir. Göçmenin önlenmesi performans seviyesini aşan kolonlarda ileri düzeyde hasarlar oluşacağı ve bu durumun yapıda kısmı göçmelere sebebiyet vereceği beklenmelidir. Deprem yer hareketlerinin hepsinde göçmenin önlenmesi performans seviyesinin düzensiz yapıda aşıldığı görülmektedir.

\section{SONUÇLAR}

$\mathrm{Bu}$ çalışmada, perdelerin plandaki yerleşiminin kirişsiz döşemeli yapıların deprem performansına olan etkileri araştırılmıştır. Bu amaçla kirişsiz döşemeli 7 katlı iki betonarme yapı tasarlanmıştır. Perdelerin ve kolonların kesit boyutları, detayları ve miktarları her iki yapıda aynıdır. Perdelerin plandaki yerleşimleri yapılardan birinde burulma düzensizliği yaratmayacak şekilde simetrik (düzenli yapı), diğerinde ise burulma düzensizliği yaratacak şekilde (düzensiz yapı) seçilmiş ve her iki yapının deprem performansı doğrusal olmayan artımsal itme analizleri ve doğrusal olmayan zaman tanım aralığında analizler ile 
irdelenmiştir. Çalışma kapsamında incelenen düzenli ve düzensiz iki yapının analiz sonuçlarına göre elde edilen bulgular ve değerlendirmeler sunulmuştur.

Perdeler planda burulma düzensizliği yaratmayacak şekilde yerleştirildiğinde, perdelerin gerekli yanal rijitliği ve dayanımı sağladığı ve yapının kontrollü hasar performans düzeyinde olduğu görülmektedir. Öte yandan perdelerin plandaki yerleşimleri yapıda burulma düzensizliği yaratacak biçimde seçilir ise perdelerin yatay taşıyıcı sistem içindeki etkinliği azalmakta ve sismik yükler sünekliği sınırlı olan kolon-kirişsiz döşeme taşıyıcı sistemi tarafından daha fazla üstlenilmektedir. Bu durumda burulma ve ikinci mertebe etkilerine bağlı olarak kolonlarda göçmenin önlenmesi performans seviyesinin üzerinde birim şekildeğiştirmeler gözlemlenmiştir. Kirişsiz döşeme elemanlarında kontrollü hasar sınırının üzerinde birim şekildeğiştirmeler oluştuğu tespit edilmiştir. Düzensiz yapıda kontrollü hasar performans seviyesi sağlanamamakla birlikte göçmenin önlenmesi performans seviyesi aşılmışıı. Örneklem sayısı kısıtlı ve limit bir durumu temsil etmekle beraber kirişsiz döşemeli sistemler için düzensiz yapıda yönetmeliğin tarif ettiği tasarım sınırlarının güvenli bölgenin dışına çıkabileceği görülmektedir.

TBDY [11] 4.3.4.6 maddesine göre süneklik düzeyi sınırlı bir taşıyıcı sistem süneklik düzeyi yüksek perdeler ile birlikte düzenlenerek süneklik düzeyi karma bir sistem olarak yapılır ise perde devrilme momentleri toplamının yapı devrilme momentine oranı $\% 75$ 'i geçmelidir. Öte yandan TBDY [11] 4.3.4.4 maddesine göre sadece kirişsiz döşemeleri içeren taşıyıcı sistemlerde deprem etkilerinin tamamının perdeler tarafından karşılanması istenmektedir. $\mathrm{Bu}$ şartı sağlamak için de hesapta çerçeve kolonlarının alttan ve üstten mafsalı alınması istenmektedir. TBDY[11] 4.3.4.6 maddesindeki koşul rijitlik ile ilgili iken TBDY [11] 4.3.4.4 maddesindeki koşul dayanım ile ilgilidir. Buna göre kirişsiz döşemeli sistemlerde perde donatılarını üst limitlere yaklaştırarak daha küçük ebatlarda ve sayıca daha az perde kullanarak bir tasarım gerçekleştirmek mümkündür. Bu durum yapıda daha az yanal rijitliğe ve kolon-kirişsiz döşeme sisteminde daha büyük şsekildeğiştirmelere sebebiyet verecektir. Göreli kat ötelenmesi limitleri ile davranış sınırlandırılmakla beraber bu limitlerin yapıların süneklik düzeylerinden bağımsız olduğu ve esnek bağlantılı cephe elemanları kullanılması durumunda iki kat arttığı göz önünde bulundurulmalıdır.

Doğrusal olmayan analiz sonuçları detaylı incelendiğinde, düzensiz yapıda perde ekseninden uzaklaşan eksenlerde performans yetersizlikleri tespit edilmiştir. Perdeler dış eksenlerdeki yerdeğiştirmeleri yeterince engelleyememiş, bunun neticesinde rijitliği ve sünekliği sınırlı kolon-kirişsiz döşeme sisteminde performans limitlerinin ötesinde şekil değiştirmeler gözlemlenmiştir. Elde edilen bulgular yapıda gözlemlenen olumsuzlukların burulma düzensizliğinin mertebesi ile ilintili olduğuna işaret etmektedir hâlbuki burulma düzensizliği TBDY'de sadece hesap yönteminin seçiminde etkili olan bir düzensizliktir, tasarımla ilgili bir sınırlama getirmemektedir. Yapı performans seviyeleri ve burulma düzensizliği arasındaki etkileşimin bir sınır değer belirlenebilmesi açısından teorik/deneysel kapsamlı bir çalışma programı ile incelenmesinin yarar sağlayacağı düşünülmektedir.

\section{Semboller}

D :Dayanım fazlalığı katsayısı

DD-2 :50 yılda aşılma olasılı̆̆ $\% 10$ (tekrarlanma periyodu 475 yıl) olan deprem yer hareketi düzeyi 
DD-3 :50 yılda aşılma olasılığı \%50 (tekrarlanma periyodu 72 yıl) olan deprem yer hareketi düzeyi

$\mathrm{f}_{\mathrm{y}} \quad$ :Yapının orta hasar sınırına karşılık gelen dayanımı

$\mathrm{f}_{\mathrm{d}} \quad$ :Yapının hafif hasar sınırına karşılık gelen dayanımı

G :Sabit yükler

GÖ : :Göçmenin Önlenmesi Performans Düzeyi

$\mathrm{H} \quad$ :Çalışan doğrultudaki kesit boyutu

KH :Kontrollü Hasar Performans Düzeyi

$\mathrm{L}_{\mathrm{p}} \quad$ :Plastik şekil değiştirme bölgesinin boyu

Q :Hareketli yükler

R :Taşıyıcı Sitem Davranış Katsayısı

$\mathrm{S}_{\mathrm{D} 1} \quad$ :1.0 s Periyot için Tasarım Spektral İvme Katsayısı

$\mathrm{S}_{\mathrm{DS}} \quad$ :Kısa Periyot Tasarım Spektral İvme Katsayısı

SH :Sinırlı Hasar Performans Düzeyi

$\alpha_{\mathrm{s}} \quad$ :Perde devrilme momentleri toplamının yapı devrilme momentine oranı

$\delta_{\mathrm{u}} \quad$ :Orta hasar sınırı yerdeğiştirme değeri

$\delta_{\mathrm{y}} \quad$ :Göçme sınırı yerdeğiştirme değeri

$\varepsilon_{\mathrm{s}} \quad$ :Donatı çeliği birim şekildeğiştirmesi

$\varepsilon_{\mathrm{c}} \quad$ :Beton birim şekildeğiştirmesi

$\eta_{\text {bi }} \quad$ :Burulma Düzensizliği Katsayısı

$\mu \quad$ :Yatay yerdeğiştirme cinsinden süneklik kapasitesi

\section{Kaynaklar}

[1] Dogangün, A., Betonarme Yapıların Hesap ve Tasarımı, İstanbul. Birsen, 2008.

[2] Mulcahy, J.F., Rotter, J.M., Moment rotation characteristics of flat plate and column systems. ACI Structural Journal, 80(2), 85-92, 1983.

[3] Chow, H.L., Selna, L.G., Seismic response of nonductile flat plate buildings. ASCE Journal of Structural Engineering, 121(1), 115-23, 1995.

[4] Hwang, S., Moehle, J. Vertical and lateral load tests of nine-panel flat-plate frame. ACI Structural Journal, 97, 193-203, 2000.

[5] Erberik, M.A., Elnashai, A.S., Fragility analysis of flat-slab structures. Engineering Structures 26(7), 937-948, 2004.

[6] Coelho, E., Candeias, P., Anamateros, G., Performance of ductile RC flat slab to steel column connections under cyclic loading. Engineering Structures, 36, 239-57, 2011. 
[7] Almeida, A.F.O., Inácio, M.M.G., Lúcio, V.J.G., Ramos, A.P., Punching behaviour of RC flat slabs under reversed horizontal cyclic loading. Engineering Structures, 117, 204-219, 2016.

[8] Sable, K.S., Ghodechor, N.A., Kandekar, S.B., Comparative Study of Seismic Behavior of Multistory Flat Slab and Conventional Reinforced Concrete Framed Structures. International Journal of Computer Technology and Electronics Engineering, 2(3), 1726, 2012.

[9] Lande, P.S., Raut, A.B., Seismic Behavior of Flat Slab System. Journals of Civil Engineering and Environmental Technology, 2(10), 7-10, 2015.

[10] DBYBHY, Deprem Bölgelerinde Yapılacak Binalar Hakkında Yönetmelik, T.C. Bayındırlık ve İskan Bakanlıgı, Türkiye, 2007.

[11] TBDY, Türkiye Bina Deprem Yönetmeliği, AFAD, Türkiye, 2018.

[12] Celep, Z., Betonarme Yapılar, İstanbul. Beta, 2009.

[13] Bayülke, N., Depreme Dayanıklı Betonarme ve Yığma Yapı Tasarımı, İzmir. İMO İzmir Şubesi, 2001.

[14] BS 8110, Structural use of concrete, part 1: code of practice for design and construction, British Standards Institution, United Kingdom, 1997.

[15] ACI 318-11, Building code requirements for structural concrete, American Concrete Institute, United States, 2011.

[16] TS 500, Betonarme Yapıların Tasarım ve Yapım Kuralları, Türk Standartları Enstitüsü, Türkiye, 2000.

[17] Macgregor, J.G., Reinforced Concrete: Mechanics and Design, New Jersey. PrenticeHall, 1988.

[18] ASCE 41-13, Seismic Evaluation and Retrofit of Existing Buildings, American Society of Civil Engineers, United States, 2014.

[19] Hwang, S.J., Moehle, J.P., Models for laterally load slabcolumn frames. ACI Structural Journal, 97, 345-353, 2000.

[20] Dovich, L.M., Wight, J.K., Effective slab width model for seismic analysis of flat slab frames. ACI Structural Journal,102(6), 868-875, 2005.

[21] ETABS 16, Extended Three Dimensional Analysis of Building Systems, Computers and Structures Inc., Berkeley, United States, 2016.

[22] Bozer, A., Effect of modelling parameters on non-linear seismic response of concrete structures. Proceedings of the Institution of Civil Engineers - Structures and Buildings, 170(12), 901-916, 2017.

[23] Chopra, A.K., Dynamics of Structures, New Jersey. Pearson Prentice Hall, 2007.

[24] Uçar, T., Düzgün, M., Betonarme Binalar İçin Artımsal İtme Analizi Esaslı Analitik Hasargörebilirlik Eğrilerinin Oluşturulması. Teknik Dergi, 24(3), 6421-6446, 2013.

[25] PEER, Ground Motion Database, University of California, Berkeley, United States, 2015. http://ngawest2.berkeley.edu 
